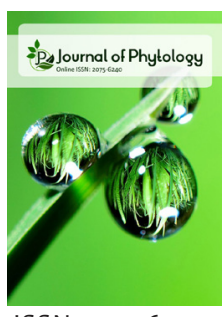

ISSN: $2075-6240$

\title{
Effect of Nettle (Urtica dioca L.) density on fiber yield and quality in a natural ecosystem under East Mediterranean conditions
}

\author{
Ioanna Kakabouki ${ }^{*}$, Charikleia Zisia, Stella Karydogiannia, \\ George Priniotakis ${ }^{\mathrm{b}}$, Mohammed K Darawsheh`, Zoi Tselia ${ }^{\mathrm{a}}$ \\ a Laboratory of Agronomy, Department of Crop Science, Agricultural University of Athens, 75 lera Odos Str., 11855 \\ Athens, Greece, bIndustrial Design and Production Engineering, University of West Attica, Egaleo Athens, Greece, \\ 'Hellenic Agricultural Organization Demeter- National Cotton Classification Centre, $1^{\text {st }} \mathrm{km}$ Karditsa-Mitropili, 43100 \\ Karditsa, Greece
}

\begin{abstract}
Nettle (Urtica dioica L.), a new industrial crop, has been cultivated since the 12 th century for its fibers. This study was conducted to specify the optimal density of plants in order to move from wild harvest to nettle cultivation. For the present study, sampling was performed in 21 different fields throughout Greece, during October 2018. The effect of nine different plant densities on several agronomic (plants height, leaf area and dry matter) and fiber quality (straw length, fiber percentage, yield, extension at break, strength, length, diameter) characteristics was determined. The higher fiber yield occurred at the lower density $\left(4\right.$ plants $\left.\mathrm{m}^{2}\right)$, while the higher fiber diameter observed at the highest density $\left(12\right.$ plants $\left.\mathrm{m}^{2}\right)$. Comparisons were performed at the $5 \%$ level of significance $(\mathrm{p} \leq 0.05)$. According to our results, there have been negative correlations between plant density and certain agronomic and quality characteristics such as plant height and fiber length, hence the optimal density is about seven plants per $\mathrm{m}^{2}$.
\end{abstract}

*Corresponding author:

Ioanna Kakabouki

Email: i.kakabouki@aua.gr

KEYWORDS: Nettle, density, wild harvest, fiber quality

\section{INTRODUCTION}

Urtica dioica is a novel industrial crop for fiber production. Since the $12^{\text {th }}$ century, fiber of wild species have been used for the fabrication of various materials [1]. This is a plant that grows in forests, fields, gardens, streets and various other areas. Nettle fibers were widely used during World War I and II as a substitute for cotton. Also, nettle was used in the same areas with flax (Linum usitatissimum L) and hemp (Cannabis sativa L.) [1]. In Germany and Austria, 500 ha of fiber nettles were cultivated for fiber production during the 1940s [1,2]. The cultivated areas of nettle were vastly reduced due to low fiber yields. At present, several Central European countries still cultivate nettle in small areas through contract farming [3]. Nettle fiber advantages include [4] increased strength, lightweight and low environmental impact. Furthermore it is a plant that can be productive from 10 to 15 years, [5] as opposed to flax, and hemp which are annual plants. Fiber removal process from the plant stems, via mechanical decortication, due to the low lignin content of the fibers [3] requires less energy than flax and hemp. Moreover, the fiber consists of cellulose $79-83.5 \%$, hemicellulose $7.2-12.5 \%$ and lignin $3.5-4.4 \%$ [6]. The age of the plants, determine the yield of the fiber. In the first year, the yield is low while in the second year, it ranges from 335 to $411 \mathrm{~kg} \mathrm{ha}^{-1}$. In addition, in the third year the yield reaches $1,016 \mathrm{~kg} \mathrm{ha}^{-1}$ [7]. It is worthy of note that plant species such as nettle, hemp and flax are renewable natural sources of fiber production [8]. Nettle could be a major source of fiber, thus contributing to the increasing demand for plant fibers in creating a variety of materials [9]. According to other studies [2], the products, which are produced from nettle fibers, are more due to the curiosity of the industries.

Due to the absence of explicit knowledge on the intensive cultivation of nettle and its characteristics, present research effort focuses on the effect of different plant densities on the agronomic and quality characteristics of nettle fiber. 


\section{MATERIALS AND METHODS}

For the present study, nettle (Urtica dioica L.) stems were collected from 21 different areas in Greece (Figure 1.). The collection took place in October 2018. The plants were, at their full flowering stage. One-year monoclonal plants were selected, in which there was no root formation yet. This leads to a lower plant density compared to plantations where roots are formed. The stems were cut at the soil level, using scythes and shears. The upper parts of the cut plants were immediately collected by hand and packed [9]. The stems were kept aligned inside the bundles.

\section{Measurements}

Selected agronomic characteristic measurements, such as plant density (No. plants $\mathrm{m}-2)$, plants' height $(\mathrm{cm})$ and leaf area per plant $\left(\mathrm{cm}^{2}\right)$, were taken on the harvest day. Fiber characteristics were measured. For this purpose, the stems were air dried for several weeks, at room temperature. The samples' dry matter as well as the plants', dry matter per $\mathrm{m}^{2}$, was then estimated. Finally, the samples' straw length was measured, by using a rule (0.1 cm precision).

The fibers were separated manually. At first, the bast part of the straw was separated. Then the obtained bast and wooden parts (sheaves), followed by the separation of short fibers from the bast part of the straw. In terms of fiber properties, in order to calculate the diameter $(\mu \mathrm{m})$, an ocular micrometer and a common ruler $(\mathrm{mm})$ along with a pair of lens was used. In addition, the fiber percentage (\%) and the fiber yield $\left(\mathrm{g} \mathrm{m}^{-2}\right)$ (eq. 1 ), which expressed on the central stem, were also determined [6],

Fiber yield $\left(\mathrm{g} \mathrm{m}^{-2}\right)=$ Fiber content $(\%) \times$ Stem Dry Matter $\left(\mathrm{g} \mathrm{m}^{-2}\right)$ eq. 1

The tensile strength (cN/tex) as well as the Extension at break factor were measured by the use of a Tinius Olsen Strength Testing Machine (Horsham, PA, USA), according to the TS ENISO 13934-1 standard [10].

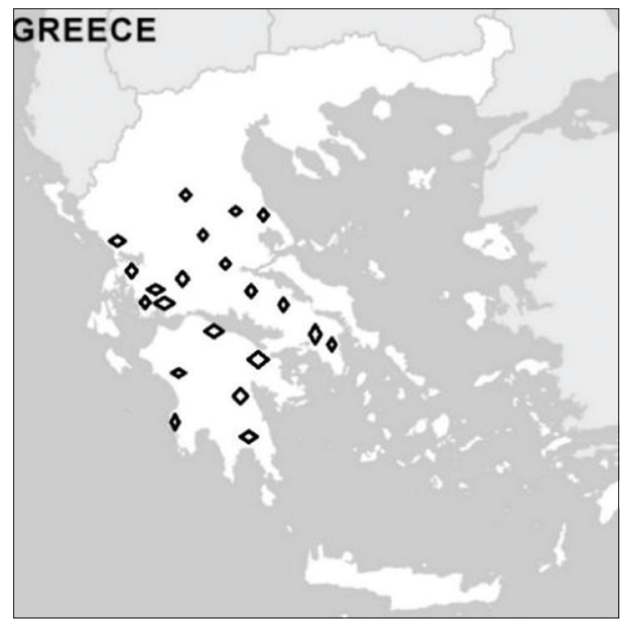

Figure 1: Sampling areas for the study

\section{Statistical Analysis}

Basic statistical analysis and analysis of variance on data was carried out using the Statistica [11] logistic package as a Completely Randomized Design. Correlation analyses were used to describe the relationships between growth parameters and yield components using Pearson's correlation. All comparisons were made at the $5 \%$ level of significance $(\mathrm{p} \leq 0.05)$.

\section{RESULTS AND DISCUSSION}

As a general rule, plant density is a key factor which particularly affects the growth of plants and their agronomic characteristics [12]. Table 1 , shows the effect of density variation on the agronomic characteristics of Urtica dioica, such as the plant height. The maximum plant height value was $159.5 \mathrm{~cm}$ for lower density value (4 plants $\mathrm{m}^{-2}$ ) while the lowest plant height value was $89.9 \mathrm{~cm}$ for a 10 plants $\mathrm{m}^{-2}$ density value. Elsewhere, a slightly higher plant height value of $170.8 \mathrm{~cm}$ has been reported [2]. Table 2 shows a negative correlation between plant density and plant height $(r=-0.742, \mathrm{p}<0.001)$, which means that at high density values, the plant height values were the lowest. The leaf area value per plant $\mathrm{cm}^{-2}$, had a negative correlation with plant density values $(\mathrm{r}=-0.985, \mathrm{p}<0.001)$ and with the dry matter per $\mathrm{m}^{-2}$ values $(\mathrm{r}=-0.644, \mathrm{p}<0.01)$, (Table 2). The highest value was 1,160.54 for lowest density $\left(4\right.$ plants $\left.\mathrm{m}^{-2}\right)$ value, and the minimum value was 474.56 in the maximum density $\left(12\right.$ plants $\left.\mathrm{m}^{-2}\right)$ value.

Also, the dry matter per plant values, ranged from 34.86 to 76.38 $\mathrm{g}_{\text {plant }}{ }^{-1}$. The maximum value was $76.38 \mathrm{~g}$ for 4 plants $\mathrm{m}^{-2}$ density value and the lowest was for 12 plants $\mathrm{m}^{-2}$ density value (Table 1 ). Similarly, [13] recorded the highest dry matter per plant value for 4 plants $\mathrm{m}^{-2}$ density value. As shown above, while the density of the plants increases, dry matter decreases something that is also been extracted from the negative correlation $(\mathrm{r}=-0.927$, $\mathrm{p}<0.001$ ) shown in Table 2 . On the contrary, dry matter per $\mathrm{m}^{2}$ increases, as the number of plants per $\mathrm{m}^{2}$ increases. A positive correlation between those two variables $(r=0.738, p<0.001)$, (Table 2), is responsible for the relation between them. The highest dry matter yield value was $476.23 \mathrm{~g} \mathrm{~m}^{-2}$ for 9 plants $\mathrm{m}^{-2}$ density value and the lowest was 305.52 for 4 plants $\mathrm{m}^{-2}$ density value (Table 1). Additionally, [6], recoded higher dry matter yield than the present study, mainly due to different weather conditions and cultivation techniques. Nettle was used as a cultivated plant [6] to study its characteristics, whereas in the present study the results came from the collection of wild nettle in different areas of Greece.

This way the ideal density to cultivate nettle in the Mediterranean conditions was also evaluated. The results of the present study in dry matter yield factor were similar with those of Bacci et al. [2] . According to their study, the lower end of the value range was lowest than the one in the present study [2]. This may be due to the management of the experimental process, which was conducted by [2], as well as the general environment of the plant development. 
Table 1: Effect of density variation on the agronomic characteristics

\begin{tabular}{|c|c|c|c|c|c|}
\hline & Density (plants $\mathrm{m}^{-2}$ ) & Height $(\mathrm{cm})$ & Leaf area $/$ plant $\mathrm{cm}^{2}$ & DM (g plant $\left.{ }^{-1}\right)$ & $\mathrm{DM}\left(\mathrm{g} \mathrm{m}^{-2)}\right.$ \\
\hline & 4 & 159.5 & $1,160.54$ & 76.38 & 305.52 \\
\hline & 5 & 120.98 & $1,047.2$ & 63.52 & 317.61 \\
\hline & 6 & 119.38 & 954.55 & 54.78 & 328.7 \\
\hline & 7 & 117.93 & 902.31 & 52.75 & 369.29 \\
\hline & 8 & 125.78 & 833.81 & 53.77 & 430.16 \\
\hline & 9 & 121.8 & 796.85 & 52.91 & 476.23 \\
\hline & 10 & 89.9 & 628.32 & 38.57 & 385.7 \\
\hline & 11 & 93.52 & 598.01 & 37.62 & 413.82 \\
\hline & 12 & 93.52 & 474.56 & 34.86 & 418.38 \\
\hline $\mathrm{F}_{\text {density }}$ & - & 2.36 & 58.02 & 16.09 & 28.40 \\
\hline Mean & 7.81 & 116.44 & 836.92 & 52.10 & 384.55 \\
\hline Sdev & 2.32 & 16.52 & 185.54 & 10.35 & 53.72 \\
\hline
\end{tabular}

Table 2: Correlation matrix between agronomic and quality characteristics

\begin{tabular}{|c|c|c|c|c|c|c|c|c|c|c|c|c|}
\hline & $\begin{array}{l}\text { density } \\
\text { (plants } \\
\mathrm{m}^{-2} \text { ) }\end{array}$ & $\begin{array}{l}\text { Height } \\
(\mathrm{cm})\end{array}$ & $\begin{array}{l}\text { leaf area / } \\
\text { plant } \mathrm{cm}^{2}\end{array}$ & $\begin{array}{c}\text { DM } \\
\left(\text { g plant }^{-1}\right)\end{array}$ & $\begin{array}{c}\text { DM } \\
\left(\mathrm{g} \mathrm{m}^{-2}\right)\end{array}$ & $\begin{array}{l}\text { straw } \\
\text { length } \\
(\mathrm{cm})\end{array}$ & $\begin{array}{c}\text { fiber } \\
\text { percentage }\end{array}$ & $\begin{array}{l}\text { fiber yield } \\
\left(\mathrm{g} \mathrm{m}^{-2}\right)\end{array}$ & $\begin{array}{c}\text { Extension } \\
\text { at break } \\
(\%)\end{array}$ & $\begin{array}{l}\text { Strength } \\
\left.(\mathrm{cN} \mathrm{tex})^{-1}\right)\end{array}$ & $\begin{array}{l}\text { fiber } \\
\text { length } \\
(\mathrm{mm})\end{array}$ & $\begin{array}{c}\text { fiber } \\
\text { diameter } \\
(\mu \mathrm{m})\end{array}$ \\
\hline$\overline{\text { dens }}$ & & & & - & $.737^{* \star *}$ & $-.737^{* * *}$ & & & $-.980^{* * *}$ & -.9 & $-.431^{\text {ns }}$ & $.342^{\text {ns }}$ \\
\hline Heig & $-.742^{* * *}$ & & .792 & $.874^{* * *}$ & $-.270^{\text {ns }}$ & $.996^{* *}$ & $-.216^{\mathrm{ns}}$ & $-.305^{\mathrm{ns}}$ & $.721^{* \star *}$ & $.706^{* * *}$ & $.802^{* \star *}$ & $-.735^{* * *}$ \\
\hline leaf a & $-.985^{* * *}$ & $.792^{* * *}$ & & $.958^{* * *}$ & $-.644^{* *}$ & $.790^{* * *}$ & $-.037^{\text {ns }}$ & $-.663^{* * *}$ & $.973^{* \star *}$ & $.957^{* * *}$ & $.500^{*}$ & $-.416^{\mathrm{ns}}$ \\
\hline $\mathrm{DM}($ & $-.927^{* * *}$ & $.874^{* * *}$ & $.958^{* * *}$ & & $-.516^{*}$ & $.879^{* * *}$ & $-.134^{\mathrm{ns}}$ & $-.545^{*}$ & $.909^{* * *}$ & $.907^{* * *}$ & $.601^{* *}$ & $-.522^{*}$ \\
\hline $\mathrm{DM}\left(\mathrm{g} \mathrm{m}^{-2}\right)$ & $.738^{* \star *}$ & $-.270^{\text {ns }}$ & $-.644^{* *}$ & $-.516^{*}$ & & $-.237^{\mathrm{ns}}$ & $-.219^{\text {ns }}$ & $.992^{* \star \star}$ & $-.713^{* * *}$ & $-.770^{\star \star *}$ & $.027^{\text {ns }}$ & $-.161^{\mathrm{ns}}$ \\
\hline straw length & $-.737^{* * *}$ & $.996^{* *}$ & $.790^{* * *}$ & $.879^{* \star *}$ & $-.237^{\text {ns }}$ & & $-.211^{\text {ns }}$ & $-.270^{\text {ns }}$ & $.714^{* * *}$ & $.697^{* * *}$ & $.810^{* * *}$ & $-.743^{* * *}$ \\
\hline fiber percentage (\%) & $.016^{\mathrm{ns}}$ & $-.216^{\text {ns }}$ & $-.037^{\text {ns }}$ & $-.134^{\text {ns }}$ & $-.219^{\text {ns }}$ & $-.211^{\mathrm{ns}}$ & & $-.101^{\text {ns }}$ & $-.011^{\text {ns }}$ & $.003^{\text {ns }}$ & $-.118^{\text {ns }}$ & $.204^{\mathrm{ns}}$ \\
\hline fiber yield $\left(\mathrm{g} \mathrm{m}^{-2}\right)$ & $.755^{* * *}$ & $-.305^{\text {ns }}$ & $-.663^{* * *}$ & $-.545^{*}$ & $.992^{* * *}$ & $-.270^{\mathrm{ns}}$ & $-.101^{\mathrm{ns}}$ & & $-.730^{* * *}$ & $-.787^{\text {***}}$ & $.009^{\text {ns }}$ & $-.135^{\mathrm{ns}}$ \\
\hline Extension at break (\%) & $-.980^{* * *}$ & $.721^{* \star \star}$ & $.973^{* * *}$ & $.909^{* * *}$ & $-.713^{* * *}$ & $.714^{* * *}$ & $-.011^{\text {ns }}$ & $-.730^{* * *}$ & & $.950^{* * *}$ & $.469^{*}$ & $-.369^{\text {ns }}$ \\
\hline Strength (cN tex ${ }^{-1}$ ) & $-.979^{* * *}$ & $.706^{* \star *}$ & $.957^{* * *}$ & $.907^{* \star *}$ & $-.770^{* * *}$ & $.697^{* \star *}$ & $.003^{\text {ns }}$ & $-.787^{* \star *}$ & $.950^{* * *}$ & & $.399^{\text {ns }}$ & $-.325^{\mathrm{ns}}$ \\
\hline fiber length ( $\mathrm{mm}$ ) & $-.431^{\mathrm{ns}}$ & $.802^{* \star \star}$ & $.500^{*}$ & $.601^{* *}$ & $.027^{\mathrm{ns}}$ & $.810^{* * *}$ & $-.118^{\mathrm{ns}}$ & $.009^{\text {ns }}$ & $.469^{*}$ & $.399^{\text {ns }}$ & & $-.955^{* * *}$ \\
\hline
\end{tabular}

Significance levels: ${ }^{*} p<0.05 ; * * p<0.01 ; * * * p<0.001$; ns, not significant $(p>0.05)$

Table 3: The quality characteristics of $U$. dioica fiber as effected by plant density

\begin{tabular}{|c|c|c|c|c|c|c|c|c|}
\hline & $\begin{array}{c}\text { Density } \\
\text { (plants } \mathrm{m}^{-2} \text { ) }\end{array}$ & $\begin{array}{l}\text { Straw length } \\
(\mathrm{cm})\end{array}$ & Fiber percentage & Fiber yield $\left(\mathrm{g} \mathrm{m}^{-2)}\right.$ & $\begin{array}{c}\text { Extension at } \\
\text { break ( \%) }\end{array}$ & Strength $\left(\mathrm{CN}\right.$ tex ${ }^{-1)}$ & $\begin{array}{c}\text { Fiber length } \\
(\mathrm{mm})\end{array}$ & $\begin{array}{c}\text { Fiber diameter } \\
(\mu \mathrm{m})\end{array}$ \\
\hline & 4 & 125 & 17.32 & 21.65 & 3.43 & 56 & 61 & 24 \\
\hline & 5 & 95.66 & 17.03 & 16.27 & 3.33 & 53.33 & 49.33 & 40.33 \\
\hline & 6 & 93.66 & 17.20 & 16.11 & 3.18 & 47.33 & 51 & 38.33 \\
\hline & 7 & 94 & 17.32 & 16.28 & 2.99 & 44.66 & 53 & 34.33 \\
\hline & 8 & 100.5 & 17.05 & 17.13 & 2.81 & 40.75 & 54 & 31.5 \\
\hline & 9 & 97 & 16.90 & 16.39 & 2.68 & 36.5 & 54.5 & 29 \\
\hline & 10 & 72 & 17.12 & 12.32 & 2.23 & 35 & 42 & 49 \\
\hline & 11 & 74 & 17.54 & 12.98 & 2.39 & 31 & 47 & 43.5 \\
\hline & 12 & 74.5 & 17.01 & 12.67 & 2.16 & 28.5 & 48 & 43.5 \\
\hline $\mathrm{F}_{\text {density }}$ & - & 2.91 & 1.19 & 25.75 & 99.24 & 54.89 & 4.84 & 2.55 \\
\hline Mean & 7.81 & 92.38 & 17.16 & 65.94 & 2.85 & 42.00 & 5.33 & 36.67 \\
\hline Sdev & 2.32 & 12.73 & 0.28 & 9.01 & 0.40 & 8.31 & 4.21 & 7.17 \\
\hline
\end{tabular}

As a result of the measurements, it was observed that the length of the straw was negatively correlated with the density of the plants $(\mathrm{r}=0.737, \mathrm{p}<0.001)$ (Table 2$)$. More specifically, the highest straw length value $(125 \mathrm{~cm})$ was observed at the lowest density value ( 4 plants per $\mathrm{m}^{2}$ ), while the lowest straw length value $(72 \mathrm{~cm})$ was at $10 \mathrm{~m}^{2}$ plants density value. Similar results were obtained by other researchers [5] in their study, in which it was reported that high plant density adversely affects the length of nettle straws as well as the bast content in them. In addition, the fiber content was higher at higher plant densities.

As mentioned above, fiber yield depends on the fiber content and the dry matter of the stems. Thus it is positively correlated $(\mathrm{r}=0.16, \mathrm{p}<0.001)$ with the density of the plants. Hence, there has been an almost $75 \%$ increase in fiber yield at the lowest density. According to Table 3 the highest value of fiber yield $21.65 \mathrm{~g} \mathrm{~m}^{-2}$ was recorded at the 4 plants $\mathrm{m}^{2}$ density value while the lowest fiber yield value $12.32 \mathrm{~g} \mathrm{~m}^{-2}$ recorded at 10 plants $\mathrm{m}^{-2}$ density value. The fiber yield was higher than other studies due to the fact that in the present study it was expressed on the central stem and not in the total weight of the plant as in the literature. There were statistically significant differences in fiber yield values between the lowest and the highest density values.

Similarly, the lower the plant density, the greater the extension at break percentage. This means that there was negative correlation 


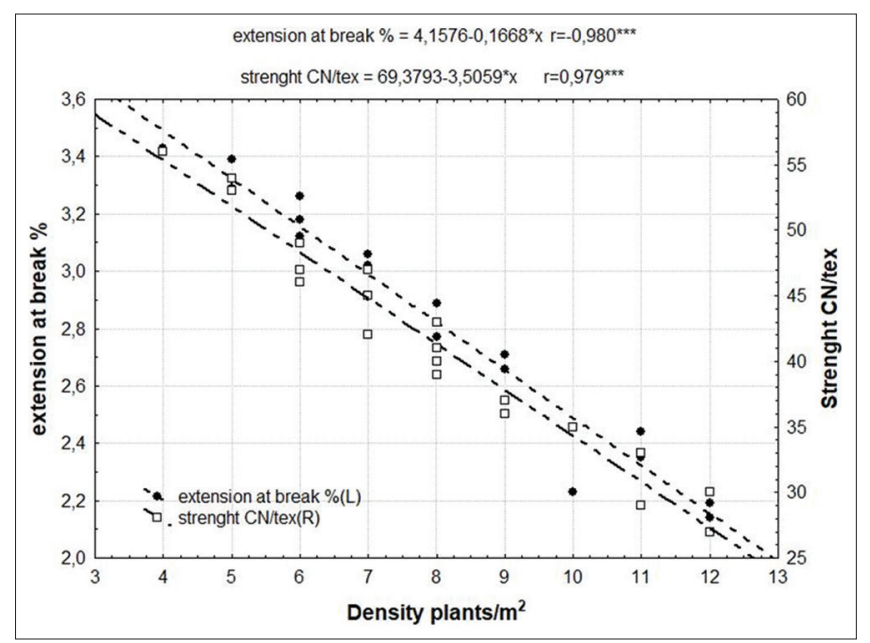

Figure 2: Double axis correlation between plant density and fiber properties

between density and extension at break $(r=0.980, \mathrm{p}<0.001)$ (Table 2). Table 3 shows that the extension at break at 4 plants $\mathrm{m}^{-2}$ density value, was $58.80 \%$ higher than at 12 plants $\mathrm{m}^{-2}$ density value. The results of the present study showed that the strength factor was also negatively correlated with plant density $(\mathrm{r}=0.979, \mathrm{p}<0.001)$ (Table 2), since the strength in the 4 plants per $\mathrm{m}^{2}$ density value was $56 \mathrm{cN} \mathrm{tex}^{-1}$ and in the 12 plants per $\mathrm{m}^{2}$ density value, was 28.5 , viz it decreased by $49.11 \%$. This is unlike other studies in which it has been reported that the lower the density, the weaker the fibers [5]. Moreover, the highest length value $(61 \mathrm{~mm})$ appeared at the lowest plant density value while the lowest length value $(42 \mathrm{~mm})$ appeared at 10 plants per $\mathrm{m}^{2}$ density value.

However, the diameter of the fibers varies widely - from 24 to $43.5 \mu \mathrm{m}$. Its highest value was calculated at the highest density value while the lowest value was at 12 plants per $\mathrm{m}^{2}$ density value. In Figure 2, the progress of extension at break is shown, as well as that of the strength factor, in relation to different plant density variations. It was observed that in the highest density values, both quality characteristics had the minimum value.

The maximum values were in the 4 plants $\mathrm{m}^{-2}$ density values, specifically the extension at break percentage was $3.4 \%$ and the strength value was $56 \mathrm{CN}$ tex ${ }^{-1}$. It is worth noting that these two characteristics of nettle fiber, follow similar course of development in different plant densities. Similar results reported by Arik et al. [10] after experimenting with chemical applications and their effect on the quality of the nettle fiber, and observed that the control sample had the highest values and while the amount of chemicals increased, so did the values of extension at break and of the strength.

\section{CONCLUSIONS}

This study demonstrates the negative correlation of plant density variation in certain agronomic and quality characteristics such as plant height and fiber length. Improved density, seems to range from 7 to 8 plants $\mathrm{m}^{-2}$. In conclusion, the density of the plants affects the growth of the nettle as well as in the quality of the fiber. This is a primary study in which the exact density in the field cultivation system was determined, compared to fertilization. This plants density formation will be followed by further research in the future.

\section{REFERENCES}

1. Vogl CR, Hartl A. Production and Processing of Organically Grown Fiber Nettle (Urtica dioica L.) and its potential use in the natural textile industry. American Journal of Alternative Agriculture. 2003; 18(3): $119-128$.

2. Hartl A, Vogl CR. Dry matter and fiber yields, and the fiber characteristics of five nettle clones (Urtica dioica L.) organically grown in Austria for potential textile use. American Journal of Alternative Agriculture. 2002;17(4): 195 - 200

3. Fischer H, Werwein E, Graupner N. Nettle fibre (Urtica dioica L.) reinforced poly (lactic acid): A first approach. Journal of Composite Materials. 2012; 46(24):3077-3087.

4. Suryawan AIGP, Suardana NPG, Winaya SIN, Suyasa BIW, Nindhia TTG. Study of stinging nettle (Urtica dioica L.) Fibers reinforced green composite materials : a review. IOP Conf. Series: Materials Science and Engineering, 2017; 201:012001.

5. Baltina I, Lapsa L, Jankauskiene Z, Gruzdeviene E. Nettle fibers as a potential natural raw material for textile in Latvia. Material Science. Materials Science. Textile and Clothing Technology. 2012;7: 23-27.

6. Bacci L, Baronti S, Predieri S, Virgilio N. Fiber yield and quality of fiber Nettle (Urtica dioica L.) cultivated in Italy. Industrial Crops and Products. 2009; 29: 480 - 484.

7. Jankauskiene Z, Gruzdeviene E. Investigation of Stinging Nettle (Urtica dioica L.) in Lithuania. Latgales Tautsaimniecības pētījumi. Sociālo zinātṇu žurnāls 2010;1(2):176 - 186.

8. Harwood J, Edom G. Nettle Fibre: Its Prospects, Uses and Problems in Historical Perspective. Textile History. 2012; 439(1):107-119.

9. Mohanty AK, Vivekanandhan S, Pin JM, Misra M. Composites from renewable and sustainable resources: challenges and innovations. Science 2018; 362:536-542.

10. Arık B, Yavas A, Avinc O. Antibacterial and wrinkle resistance improvement of nettle biofiber using chitosan and BTCA. Fibres \& Textiles in Eastern Europe 2017; 25, 3(123): 106-111.

11. Statsoft, Inc., Statistica (data analysis software system). Ver. 10 www.statsoft.com (2011)

12. Caliskan SM, Aslan M, Uremis I, Caliskan EM. The effect of row spacing on yield and yield components of full season and double cropped soybean. Turkish Journal of Agriculture and Forestry. 2007; 31:147-154.

13. Jankauskiene Z, Gruzdeviene E. Changes in the productivity of wild and cultivated stinging nettle (Urtica dioica L.) as influenced by the planting density and crop age. Zemdirbyste-Agriculture 2015; 102(1): 31-40. 